\title{
PENGARUH HASIL BELAJAR YANG MENGGUNAKAN MODEL PROBLEM BASED LEARNING DENGAN PEMBELAJARAN KONVENSIONAL PADA MATERI SUHU DAN KALOR DI KELAS X SEMESTER II SMA NEGERI 1 PAGARAN T.P. 2015/2016
}

\author{
Pretty Silaban dan Abd. Hakim S \\ Jurusan Fisika FMIPA Universitas Negeri Medan \\ Jalan Willem Iskandar Pasar V Medan, Sumatera Utara \\ silabanpretty@yahoo.com
}

\begin{abstract}
ABSTRAK
Penelitian ini bertujuan untuk mengetahui pengaruh hasil belajar yang menggunakan model PBL dengan pembelajaran konvensinal pada materi suhu dan kalor di kelas $\mathrm{X}$ semester II SMA Negeri 1 Pagaran T.P. 2015/2016. Jenis penelitian ini adalah quasi experiment dengan desain control group pretest-posttest. Pengambilan sampel dilakukan dengan cara cluster random sampling dengan mengambil dua kelas dari enam kelas yaitu kelas X-3 sebagai kelas eksperimen dan kelas X-5 sebagai kelas kontrol yang masing-masing berjumlah 32 orang. Instrumen yang digunakan berupa tes hasil belajar dalam aspek pengetahuan berbentuk uraian yang terdiri dari 8 soal yang sudah divalidasi dan digunakan juga lembar observasi digunakan untuk mengukur aktivitas, sikap dan keterampilan. Berdasarkan analisis data untuk kelas eksperimen yang diajarkan menggunakan model PBL diperoleh rata-rata pretes 28,22 dan nilai rata-rata postes 74,22. Kelas kontrol yang diajarkan dengan pembelajaran konvensional diperoleh rata-rata pretes 26,95 dan rata-rata postes 66,41 . Berdasarkan hasil uji hipotesis (uji-t) yang digunakan untuk melihat pengaruh hasil belajar menggunakan model PBL diperoleh kesimpulan bahwa ada pengaruh hasil belajar yang signifikan terhadap hasil belajar menggunakan model PBL pada materi suhu dan kalor di kelas X semester II SMA Negeri 1 Pagaran T.P. 2015/2016. Berdasarkan hasil analisis regresi linear yang digunakan untuk melihat pengaruh aktivitas terhadap hasil belajar diperoleh kesimpulan bahwa ada pengaruh aktivitas terhadap hasil belajar.
\end{abstract}

Kata kunci : model PBL, hasil belajar, aktivitas.

\begin{abstract}
This research purposes to know the effect of learning outcomes using PBL model with conventional learning in the subject matter of temperature and heat in $\mathrm{X}$ grade of second semester SMAN 1 Pagaran academic year 2015/2016. This research is quasi experiment with contol group pretest-posttest design. Sampling was determined by cluster random sampling by taking two classes of six classes, which class X-3 as the experimental class and class X-5 as the control class, each classes has 32 students. The instrument was used kognitive learning outcomes with multiple choice as much as 8 questions that have been validated, and was used observation sheet to measure the activity, affective, and psycomotoric. The results of the research data showed the average pretest and postest of class that using PBL model was 28,22 and 74,22. The average pretest and postest of class that using conventional learning was 26,95 and 66,41 . Based on the results of hypothesis testing (t-test), we concluded that there was a significant effect of learning outcomes which using PBL model in the subject matter of temperature and heat subject in X grade of second semester SMAN 1 Pagaran academic
\end{abstract}


year 2015/2016. . Based on the result of analysis linear regression was showed there was an effect of activity toward learning outcomes.

Keywords: PBL, learning outcomes, activity.

\section{PENDAHULUAN}

Pusat Penilaian Pendidikan Balitbang Kemdikbud menyatakan bahwa rata-rata nilai UN SMA/ MA pada tahun 2012/2013 yakni 6,35 dan mengalami penurunan pada tahun 2013/2014 menjadi 6,12. Adapun nilai tertinggi UN 2013/2014 adalah 8,17 dan yang terendah adalah 3,45 . Hal ini menunjukkan bahwa hasil belajar siswa SMA/MA di Indonesia masih rendah, khususnya pada pelajaran fisika. Berdasarkan hasil wawancara dengan salah satu guru bidang studi fisika di SMA N. 1 Pagaran diperoleh data bahwa: (1) kriteria ketuntasan minimal (KKM) adalah 65, (2) nilai rata-rata hasil ujian harian siswa semester I T.A 2014/2015 sebesar 56 dan nilai rata-rata hasil ujian tengah semester fisika siswa semester I T.A 2014/2015 sebesar 45.(3) Model pembelajaran yang digunakan guru masih kurang bervariasi, pembelajaran masih berpusat pada guru (4) siswa jarang melakukan eksperimen.

Berdasarkan hasil angket yang disebarkan kepada 32 siswa di kelas $\mathrm{X}$ SMA N.1 Pagaran diperoleh hasil bahwa 69\% siswa tidak dapat memberikan contoh masalah fisika yang pernah mereka pelajari dan 59\% siswa belum mampu menganalisis masalah fisika. Berdasarkan hasil uji soal semester tipe $\mathrm{C} 4$ diperoleh data bahwa $74 \%$ siswa tidak dapat menganalisis soal tersebut, hanya 26\% siswa yang mampu menganalisis soal yang diujikan. Instrumen soal ujian semester yang digunakan memiliki tingkat analisis yang masih rendah jika dibandingkan dengan soal ujian akhir nasional (UAN) maupun soal seleksi nasional masuk perguruan tinggi negeri (SNMPTN). Nilai rata-rata hasil ujian fisika yang rendah merupakan gambaran kurangnya tingkat kemampuan siswa menguasai materi berupa konsep-konsep materi pelajaranserta aplikasinya dalam bentuk soal-soal pelajaran.

Berdasarkan hasil observasi yang dilakukan penulis masalah yang diperoleh adalah hasil belajar di bawah KKM, siswa jarang melakukan eksperimen, kemampuan menganalisis masalah masih rendah, dan kemampuan menganalisis soal masih rendah. Berhubungan dengan masalah tersebut maka dipilih model problem based learning (PBL). Model PBL mampu meningkatkan aktivitas dan hasil belajar siswa. Trianto (2009) menyatakan bahwa model PBL dikembangkan untuk membantu siswa mengembangkan kemampuan berpikir, pemecahan masalah dan keterampilan intelektual, belajar berbagai peran orang dewasa melalui perlibatan mereka dalam pengalaman nyata dan menjadi pebelajar yang otonom dan mandiri. Arends (2008) menyatakan bahwa model PBL memiliki lima tahap pembelajaran, yaitu: (1) memberikan orientasi tentang permasalahan kepada siswa, (2) mengorganisasikan siswa untuk meneliti, (3) membantu investigasi mandiri dan kelompok , (4) mengembangkan dan mempresentasikan artefak dan exibit, (5) menganalisis dan mengevaluasi proses mengatasi masalah.

Arends (2008) menyatakan bahwa model PBL digunakan untuk mendukung pemikiran tingkat tinggi dalam situasi berorientasi masalah, seperti pengajaran berbasis proyek, pembelajaran autentik, dan pembelajaran bermakna. Penerapan model PBL ini sudah pernah diteliti oleh beberapa peneliti sebelumnya seperti Aziz, dkk., (2014) dari hasil penelitian diketahui model PBL dapat meningkatkan keterampilan belajar mandiri siswa dalam memecahkan masalah. Yoesoef (2015) dari hasil penelitian diketahui kemampuan 
menanya dan penguasaan konsep siswa mengalami peningkatan.

Penelitian ini bertujuan untuk melihat pengaruh hasil belajar menggunakan model PBL pada materi suhu dan kalor di kelas $\mathrm{X}$ semester II SMA Negeri 1 Pagaran T.P. 2015/2016.

\section{METODE PENELITIAN}

Penelitian ini dilaksanakan di SMA Negeri 1 Pagaran, Simamora Nabolak Kecamatan Pagaran, Kabupaten Tapanuli Utara. Waktu penelitian pada semester genap tahun pelajaran 2015/2016. Populasi dalam penelitian ini adalah seluruh siswa kelas X SMA Negeri 1 Pagaran Tahun Pelajaran 2015/2016 yang terdiri dari 6 kelas. Sampel kelas diambil dari populasi yaitu sebanyak 2 kelas, satu kelas dijadikan kelas eksperimen yaitu kelas X-3 diajarkan dengan model PBL dan satu kelas lagi dijadikan kelas kontrol yaitu X-5 diajarkan dengan pembelajaran konvensional.

Penelitian ini termasuk jenis penelitian quasi eksperimen dan desain penelitian yang digunakan adalah control group pretest-postest design. Rancangan penelitian ini ditunjukkan pada tabel 1.

Tabel 1. Two Group Pretest-Postest Design

\begin{tabular}{|l|l|l|l|}
\hline Kelas & Pretest & Perlakuan & Posttest \\
\hline Eksperimen & T & X & T \\
\hline Kontrol & T & Y & T \\
\hline
\end{tabular}

Keterangan:

Pre-Test =Tes yang dilakukan kepada kelas eksperimen dan kontrol sebelumm perlakuan model pembelajaran

Post-TesT =Tes yang dilakukan kepada kelas eksperimen dan kontrol setelah perlakuan model pembelajaran

$\mathrm{T}=$ =Pemberian tes hasil belajar

$\mathrm{X} \quad=$ Perlakuan dengan menggunakan model PBL

Y menggunakan konvensional

Uji lilliefors digunakan untuk melihat apakah sampel berdistribusi normal atau tidak. Uji homogenitas digunakan untuk mengetahui apakah sampel yang diambil varians homogen atau tidak. Pengujian hipotesis digunakan uji beda (ujit).

\section{HASIL DAN PEMBAHASAN Hasil Penelitian}

Penelitian ini melibatkan dua kelas yang diberi model pembelajaran yang berbeda yaitu pada kelas eksperimen menggunakan model PBL dan pada kelas kontrol menggunakan pembelajaran konvensional. Sebelum ke dua kelas diberi perlakuan kedua kelas terlebih dahulu diberikan pretes yang bertujuan untuk mengetahui kemampuan awal siswa.

Berdasarkan hasil pretes yang diperoleh, nilai rata-rata kelas eksperimen 28,22 dan nilai kelas kontrol 26,95. Selanjutnya kelas eksperimen dan kelas kontrol diberikan perlakuan yang berbeda. Pada kelas eksperimen menggunakan model PBL dan pada kelas kontrol menggunakan pembelajaran konvensional. Setelah ke dua kelas diberi perlakuan, masing-masing kelas diberi postes untuk melihat adanya pengaruh akibat diberikan perlakuan pembelajaran yang berbeda. Nilai rata-rata postes kelas eksperimen sebesar 74,22 dan kelas kontrol sebesar 66,41.

Berdasarkan hasil uji normalitas dengan menggunakan uji Lilliefors untuk ke dua sampel diperoleh bahwa nilai pretes dan postes berdistribusi normal dan berdasarkan uji kesamaan dua varians diperoleh bahwa kelompok sampel yang digunakan berasal dari populasi yang homogen. Karena data ke dua sampel dinyatakan normal dan homogen sehingga layak dilakukan uji hipotesis dan hasilnya ditunjukkan pada tabel 4.

Tabel 4. Hasil Uji Hipotesis Data Pretes

\begin{tabular}{|c|l|c|c|c|}
\hline Data & \multicolumn{1}{|c|}{ Kelas } & $\mathbf{t}_{\text {lining }}$ & $\mathbf{t}_{\text {thd }}$ & Keterangan \\
\hline \multirow{2}{*}{ Pretes } & Eksperimen & 0,487 & 1,999 & $\begin{array}{c}\text { Kemampuan } \\
\text { awal sama }\end{array}$ \\
\cline { 2 - 5 } & Kontrol & 0,43 & 1,669 & Ada pengaruh \\
\hline Postes & Eksperimen & 2,373 & 1,60 & \\
\hline
\end{tabular}




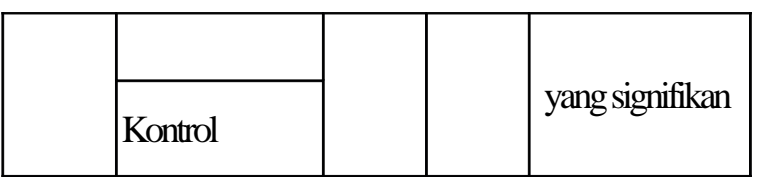

Berdasarkan hasil yang diperoleh $\mathrm{t}_{\text {hing }}>$ $\mathrm{t}_{\text {tate }}(2,373>1,669)$ dapat disimpulkan bahwa ada pengaruh yang signifikan terhadap hasil belajar menggunakan model PBL pada materi suhu dan kalor di kelas X semester II SMA Negeri 1 Pagaran T.P. 2015/2016.

Observasi pada penelitian ini bertujuan untuk mengetahui perkembangan psikomotorik ,afektif dan mengetahui pengaruh aktivitas terhadap hasil belajar menggunakan model PBL.Indikator aktivitas yang dinilai adalah merumuskan masalah, mengumpulkan data verifikasi, mengumpulkan data eksperimen, menganalisis data percobaan, merumuskan kesimpulan.

Berdasarkan hasil observasi psikomotorik siswa pada kelas eksperimen diketahui bahwa perkembangan psikomotorik siswa dari pertemuan I sampai pertemuan ke IV mengalami peningkatan. Adapun rata-rata perkembangan psikomotorik siswa pada kelas eksperimen yaitu 73,08 dengan kategori baik. Observasi psikomotorik hanya dilakukan di kelas eksperimen karena keterampilan yang dinilai adalah keterampilan saat siswa melakukan eksperimen dengan menggunakan Lembar Kerja Siswa (LKS). Berdasarkan Hasil observasi diketahui bahwa afektif siswa pada kelas eksperimen lebih tinggi daripada afektif siswa pada kelas kontrol. Adapun rata-rata perkembangan afektif siswa pada kelas ekperimen yaitu 74,25 dengan kategori baik dan rata-rata perkembangan afektif siswa pada kelas kontrol yaitu 51,56 dengan kategori cukup baik.

Hasil observasi aktivitas pada kelas eksperimen menunjukkan bahwa ada pengaruh aktivitas terhadap hasil belajar berdasarkan kategori, individu dan kelompok. Adapun pengaruh aktivitas berdasarkan kategori yang paling rendah sampai yang paling tinggi ditunjukkan pada Gambar 1.

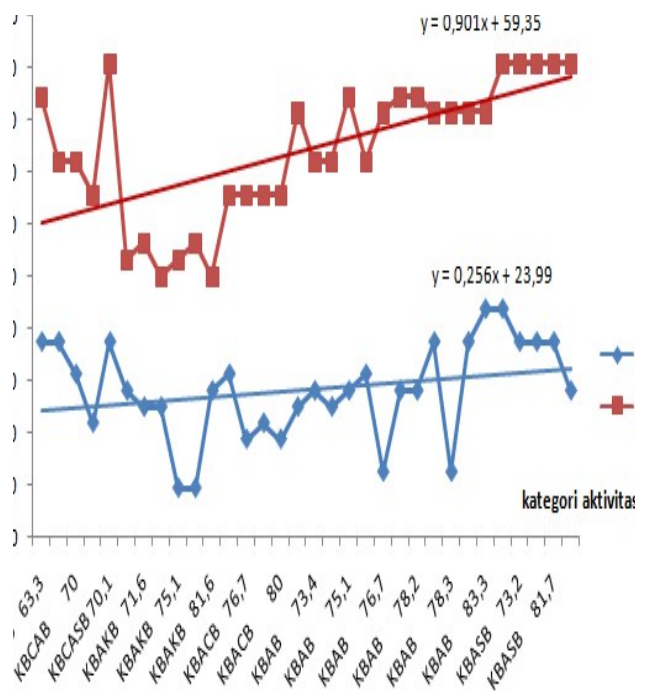

Gambar 1. pengaruh aktivitas terhadap hasil belajar berdasarakan kategori.

Aktivitas berdasarkan kategori disusun dari urutan nilai pretes,aktivitas, dan postes yang diperoleh masing-masing siswa.

Keterangan:

KBCAB :kurang baik, cukup aktif, baik

KBCASB :kurang baik, cukup aktif, sangat baik.

KBAKB :kurang baik, aktif, kurang baik

KBACB :kurang baik, aktif, cukup baik

KBAB :kurang baik, aktif, baik

KBASB :kurang baik, aktif, sangat baik

Hasil observasi pengaruh aktivitas terhadap hasil belajar berdasarkan individu ditunjukkan pada Gambar 2. 


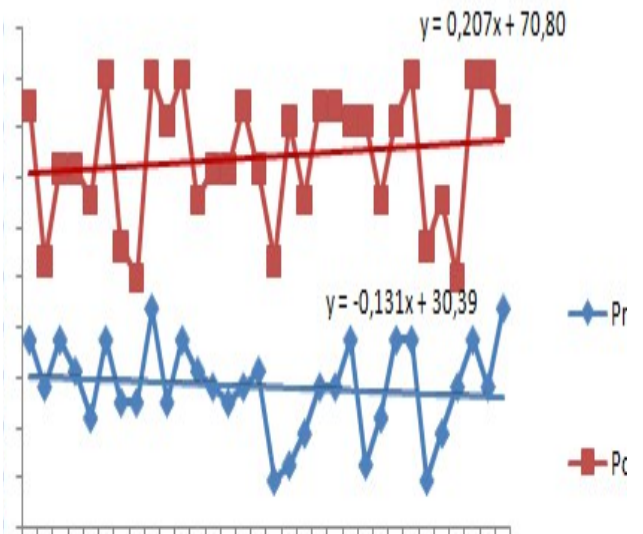

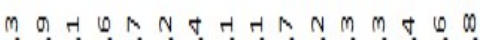
aktivitas ind

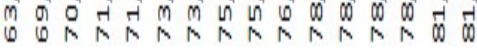

\section{$\mathrm{Ga}$}

mbar 2. pengaruh aktivitas terhadap hasil belajar berdasarakan individu.

Hasil observasi pengaruh aktivitas terhadap hasil belajar berdasarkan kelompok ditunjukkan pada Gambar 3.

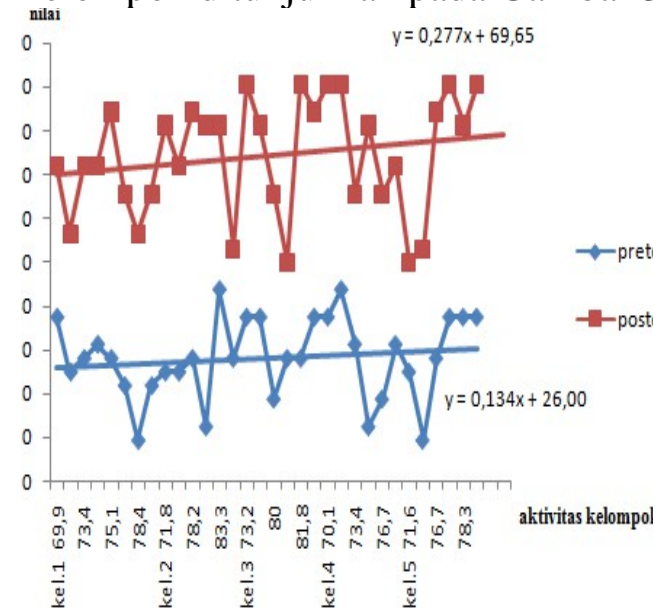

Gambar 3. pengaruh aktivitas terhadap hasil belajar berdasarkan kelompok.

Berdasarkan Gambar 3, Aktivitas kelompok disusun berdasarkan urutan nilai aktivitas dari setiap anggota dalam satu kelompok dari yang terendah sampai yang tertinggi.

Persamaan linear $y=a x+b$ memiliki nilai a yang menyatakan kemiringan garis. Nilai a pada persamaan linier pretes $\left(\mathrm{a}_{\text {pre }}\right)$ menjadi acuan kriteria dalam menentukan berpengaruh atau tidaknya nilai aktivitas. Adapun kriterianya adalah sebagai berikut :

$$
\mathrm{a}_{\text {post }}>\mathrm{a}_{\text {pre }} \quad \text { nilai aktivitas }
$$
mempengaruhi hasil belajar (nilai postes)

$a_{\text {post }}<a_{\text {pre }}:$ nilai aktivitas tidak mempengaruhi hasil belajar (nilai postes)
Berdasarkan hasil observasi aktivitas yang ditunjukkan pada gambar 1, gambar 2, dan gambar 3 diketahui bahwa pada ketiga gambar ditunjukkan bahwa $a_{\text {post }}$ $>a_{\text {pre }}$, hal ini berarti nilai aktivitas mempengaruhi hasil belajar (nilai postes) atau aktivitas memberi sumbangan yang besar terhadap hasil belajar dengan menggunakan model PBL.

\section{Pembahasan}

Perolehan nilai rata-rata pretes siswa di kelas kontrol sebesar 26,95 dan nilai ratarata postes sebesar 66,41 sedangkan di kelas eksperimen diperoleh nilai rata-rata pretes siswa sebesar 28,22 dan nilai ratarata postes sebesar 74,22. Hasil penelitian menunjukkan bahwa ada pengaruh hasil belajar dengan menggunakan model PBL materi Suhu dan Kalor di kelas X semester II SMA N 1 Pagaran. Hal ini dapat dilihat dengan adanya perbedaan hasil belajar dan hasil observasi aktivitas antara kelas eksperimen dengan kelas kontrol.

Selama penelitian berlangsung kronologi pada pertemuan pertama hingga pertemuan keempat diperoleh bahwa pada fase pertama yaitu memberikan orientasi tentang permasalahan kepada siswa. Guru memberikan masalah terhadap siswa pada fase orientasi siswa terhadap masalah, adapun masalah yang diberikan terdapat pada lembar kerja siswa. Setelah lembar kerja siswa dibagikan aktivitas yang muncul dari siswa yaitu siswa mampu merumuskan masalah. Adapun hal yang dilakukan siswa pada tahap ini yakni siswa harus memperhatikan prosedur yang disajikan guru, siswa mengidentifikasi masalah yang disajikan, menjawab pertanyaan yang diajukan guru. Siswa belum semua mampu mengidentifikasi masalah, masih ada sebagian siswa yang bingung dengan masalah yang disajikan karena pembelajaran dengan model PBL masih terasa asing dalam pikiran mereka sehingga peneliti menjelaskan berulang kembali mengenai masalah yang disajikan hingga mereka paham apa yang dimaksud pada masalah tersebut, tetapi setelah dilihat dari pertemuan kedua dan ketiga siswa 
semakin paham mengenai masalah yang disajikan hingga pertemuan keempat siswa tidak lagi bingung dan komentar mengenai masalah, hal ini dikarenakan semakin terbiasanya siswa dalam merumuskan masalah yang disajikan. Ketika siswa mampu merumuskan masalah, hal ini menjadi salah satu indikator kesuksesan untuk meningkatkan hasil belajar.

Fase kedua yaitu mengorganisasi siswa untuk belajar, pada fase ini guru membimbing siswa untuk mengumpulkan data verifikasi dan aktivitas yang muncul dari siswa yaitu siswa dapat mengumpulkan informasi, mengajukan pertanyaan, dan mampu menuliskan hipotesis pada lembar kerja siswa. Siswa dituntut agar mampu berpikir kritis dalam tahap ini karena mereka harus menuliskan hipotesis dari masalah yang disajikan oleh peneliti.

Siswa masih kebingungan pada pertemuan pertama dalam membuat hipotesis sehingga penulis penulis harus menerangkan kembali apa yang dimaksud dengan hipotesis dan bagaimana cara menyusun hipotesis. Sehingga siswa mampu menuliskan hipotesis sesuai dengan masalah yang disajikan, pada pertemuan kedua beberapa kelompok sudah mampu menuliskan hipotesis dari masalah yang disajikan walaupun belum sepenuhya benar, dan dipertemuan keempat hampir semua kelompok sudah bisa menuliskan hipotesis dengan benar dan sesuai dengan masalah yang disajikan.

Kemampuan siswa dalam menuliskan hipotesis mendukung tercapainya indikator penilaian mengumpulkan data verifikasi sehingga ketika siswa mampu menuliskan hipotesis, mengajukan pertanyaan tentang masalah yang disajikan, dan siswa mampu mengumpulkan informasi terkait dengan masalah yang disediakan dalam lembar kerja siswa maka hasil belajar siswa akan meningkat.

Fase ketiga dari model PBL adalah membimbing penyelidikan individu atau kelompok. Guru membimbing siswa untuk mengumpulkan data eksperimen dan aktivitas yang muncul pada tahap ini yaitu siswa melakukan percobaan dengan teman kelompoknya, melaksanakan prosedur percobaan sesuai bimbingan guru dan petunjuk praktikum yang sudah ada pada lembar kerja siswa, kemudian siswa harus mencatat data hasil percobaan. Membutuhkan waktu yang agak lama pada tahap ketiga ini karena disinilah siswa melakukan percobaan, mengamati pecobaan, dan mencatat hasil percobaan. Tahap inilah yang mendukung siswa agar mampu menarik kesimpulan dari masalah yang disajikan. Kemampuan siswa saat melakukan percobaan dengan teman kelompok, melakukan prosedur sesuai bimbingan, dan mencatat hasil percobaan merupakan faktor yang sangat mendukung peningkatan hasil belajar.

Pengaruh hasil belajar menggunakan model PBL memberikan perbedaan terhadap hasil dikarenakan model PBL mempunyai tiga konsep utama yaitu pengetahuan yang didapat dari proses penyelidikan autentik yang berupa masalah, siswa dapat mengembangkan kemampuan untuk menyimpulkan dari penyelidikan yang telah dilakukan (knowledge) dan siswa menganalisis unsurunsur yang diperlukan, melaksanakan percobaan dan mempresentasikan hasil karya. Pembelajaran berdasarkan masalah dikembangkan untuk membantu siswa mengembangkan kemampuan berpikir, pemecahan masalah dan keterampilan intelektual, belajar berbagai peran orang dewasa melalui pelibatan mereka dalam pengalaman nyata atau simulasi, dan menjadi pebelajar yang otonom dan mandiri (Trianto, 2009). Hal ini juga didukung oleh teori konstruktivisme bahwa dalam model PBL pengetahuan dibangun oleh siswa sendiri secara aktif baik melalui proses personal maupun sosial. Teori konstruktivis sesuai dengan model PBL yang mengharuskan siswa melakukan penyelidikan autentik untuk mencari penyelesaian nyata terhadap masalah nyata dan sebagai suatu proses dimana anak secara aktif membangun sistem makna dan 
pemahaman realitas melalui pengalaman dan interaksi-interaksi mereka.

Siswa harus menganalisis dan mendefinisikan masalah, mengembangkan hipotesis, dan membuat ramalan, mengumpulkan dan menganalisa informasi, melakukan eksperimen dan merumuskan kesimpulan, serta metode penyelidikan yang digunakan harus bergantung kepada masalah yang sedang dipelajari.

Fase keempat mengembangkan dan mempresentasikan artefak dan exhibit, pada tahap ini guru mengarahkan dan membimbing siswa untuk menganalisis data percobaan yang telah mereka dapatkan saat melakukan percobaan dan yang dilakukan siswa pada tahap ini yaitu mengolah data, merumuskan hasil percobaan, menjelaskan/mempresentasikan hasil diskusi di depan kelas. Pertemuan pertama siswa masih malu-malu dan ragu-ragu mempresentasikan hasil karya mereka. Siswa masih harus diberikan motivasi agar berani mempresentasikan hasil karyanya, sedangkan pada pertemuan kedua hingga ketiga siswa semakin semangat untuk mempresentasikan hasil karyanya dan sudah mulai ada siswa yang meberikan saran-saran dan pertanyaan kepada kelompok penyaji. Semua kelompok pada pertemuan keempat sudah memiliki rasa percaya diri yang tinggi untuk mempresentasikan hasil karya mereka dan seamkin banyak siswa yang memberikan saran-saran dan pertanyaan sehingga siswa menjadi aktif dan pembelajaran berlangsung dengan baik. Hal ini didukung oleh Arends (2008) pembelajaran berdasarkan masalah merupakan suatu pendekatan pembelajaran di mana siswa mengerjakan permasalahan yang autentik dengan maksud untuk menyusun pengetahuan mereka sendiri, mengembangkan inkuiri dan keterampilan berpikir tingkat lebih tinggi, mengembangkan kemandirian dan percaya diri.

Fase kelima menganalisis dan mengevaluasi proses pemecahan masalah, pada tahap ini guru menganalisis dan mengevaluasi apa yang telah disampaikan oleh siswa saat mempresentasikan hasil karya. Guru mengoreksi kesalahan atau kekurangan siswa saat mempresentasikan hasil percobaan/diskusi dan memberi penguatan kepada siswa kalau apa yang disampaikan siswa sudah benar. Aktivitas yang dilakukan siswa pada fase ini yaitu mendengarkan penjelasan guru, mencatat kesimpulan dari apa yang disampaikan guru, dan memberikan menyampaikan pertanyaan kepada guru jika ada hal yang belum dimengerti. Pada fase pertama belum ada siswa yang yang ingin bertanya tentang materi yang sedang dibahas, dipertemuan kedua masih masih 2 atau 3 orang yang ingin bertanya kepada peneliti, namun dipertemuan keempat jumlah yang ingin bertanya lebih dari yang sebelumnya.

Kemampuan siswa bertanya sangat mendukung peningkatan hasil belajar karena hal ini merupakan indikator aktivitas bahwa siswa mengerti dengan apa yang sedang dibahas. Hal ini didukung oleh penelitian Yoesoef (2015) yang menyatakan bahwa model PBL dapat meningkatkan kemampuan bertanya siswa dan penguasaan konsep siswa, dimana ketika kemampuan bertanya dan penguasaan konsep siswa meningkat aktivitas siswa meningkat sehingga hasil belajarpun meningkat.

Berdasarkan uraian pembelajaran dari fase satu sampai lima dapat disimpulkan bahwa aktivitas sangatlah mempengaruhi hasil belajar. Semua penilaian aktivitas untuk setiap fase pada model PBL saling berkaitan semuanya mulai dari fase pertama sampai kelima. Adanya peningkatan pada hasil belajar didukung semua indikator penilaian aktivitas. Sehingga ketika aktivitas meningkat maka hasil belajar meningkat. Hal ini didukung oleh penelitian terdahulu yaitu Selcuk, et all., (2015) yang menyatakan bahwa ada perbedaan hasil belajar fisika yang signifikan dengan menggunakan model PBL dibandingkan dengan pembelajaran konvensional. Hal ini didukung oleh Adi, dkk., (2014) yang 
menyatakan bahwa model PBL dapat meningkatkan aktivitas dan hasil belajar siswa.

Sanjaya (2006) juga menyatakan bahwa model PBL juga memiliki kelebihan meningkatkan aktivitas pembelajaran siswa. Berdasarkan hasil observasi keterampilan dan sikap yang dilakukan peneliti, juga dapat disimpulkan bahwa model PBL juga meningkatkan keterampilan dan sikap siswa hal ini didukung oleh Aziz, dkk., (2014) yang menyatakan bahwa model PBL dapat meningkatkan keterampilan belajar yang lebih baik dibandingkan dengan pembelajaran konvensional.Adapun beberapa hal yang perlu dibenahi, yakni dalam pembagian kelompok dan manajemen waktu saat pembelajaran. Pada saat pembagian kelompok diskusi, kondisi kelas kurang kondusif karena siswa belum terbiasa dengan penerapan model PBL dan sebaiknya jumlah siswa dalam satu kelompok cukup 4-5 orang, serta penggunaan waktu saat pembelajaran harus diefektifkan supaya tiap-tiap tahap dalam model PBL berjalan dengan baik.

\section{KESIMPULAN DAN SARAN Kesimpulan}

Berdasarkan analisis data hasil penelitian dapat disimpulkan bahwa ada pengaruh yang signifikan terhadap hasil belajar menggunakan model PBL pada materi suhu dan kalor di kelas $\mathrm{X}$ semester II SMA Negeri 1 Pagaran T.P. 2015/2016

\section{Saran}

Adapun saran untuk peneliti selanjutnya sebagai berikut: (1) Jumlah siswa dalam satu kelompok cukup 4-5 siswa. (2) Peneliti selanjutnya agar lebih mampu mengkondisikan kelas saat pembentukan kelompok diskusi.
Manajemen waktu untuk setiap tahap dari model PBL perlu diperhatikan lagi.

\section{DAFTAR PUSTAKA}

Adi, N.P., Ayu, N., dan Nuvitalia, D., (2014), Penerapan Model Pembelajaran PBL Pokok Bahasan Kalor Untuk Meningkatkan Hasil Belajar Siswa Kelas X SMA N 11 Semarang, Prosiding Mathematics and Sciences 1(1):286-289.

Arends, R.I., (2008), Learning to Teach Jilid II, Pustaka Pelajar, Yogyakarta.

Aziz, M.S., Zain, A.N., Samsudin,M.A., dan Saleh, S., (2014), The Effects Of Problem-Based Learning On Self- Directed Learning Skills Among Physics Undergraduates, International Journal of Academic Research in Progressive Education and Development 3(1): 131-134.

Sanjaya, W., (2006), Strategi

Pembelajaran Berorientasi

Standar Proses Pendidikan,

Kencana Prenada Media Grup, Jakarta.

Selcuk, G.S., Caliskan, S., dan Sahin, M., (2015), A Comparison Of Achievement In Problem-Based, Strategic And Traditional Learning Classes In Physics, International Journal on Trends in Education and Their Implications 4(1): 158-160.

Trianto. (2009). Mendesain Model Pembelajaran InovatifProgresif, Kencana Prenada Media Grup.

Yoesoef, A., (2015), Penerapan Model PBL untuk Meningkatkan Kemampuan Menanya dan Penguasaan Konsep Fisika Kelas $X$ MIA 1 SMA Negeri 2 Kediri, Jurnal PINUS 1(2): 100-101. 